\title{
TIESISKUMA APDRAUDĒJUMS. POLIJAS PIEMĒRS
}

\section{RULE OF LAW CRISIS. POLAND}

\section{Viktorija Soneca, ${ }^{1}$ LL.M}

Latvijas Universitātes Juridiskās fakultātes doktorante

\section{Summary}

In this paper, the author provides an analysis of the Article 7 of TEU in context of infringement procedures and the CJEU's case No. C-619/18 Commission v. Poland. Article 7 of TEU is a mechanism that ensures that all member states respect the common values of the EU. Such mechanism for the first time has been triggered in case of Poland on the basis of its judicial reforms, as there is a clear risk that this member state is breaching the fundamental values of EU - rule of law (Article 2 of TEU).

Atslēgvārdi: LES 7. pants, pamatvērtības, tiesiskums

Keywords: Article 7 of the Treaty on European Union, rule of law, values of EU

\section{Ievads}

N̦emot vērā notikumus² Polijas Republikā (turpmāk - Polija), kas cita starpā ietver Eiropas Komisijas (turpmāk - Komisija) celto prasību pret Poliju (C-619/18 Komisija/Polija), kā arī Eiropas Padomes (turpmāk - Padome) uzsākto Līguma par Eiropas Savienību (turpmāk - LES) 7. panta procedūru pret minēto dalībvalsti, šajā rakstā apskatīts Eiropas Savienības (turpmāk - ES) likumdevēja izstrādātais LES 7. panta mehānisms, kura mērķis ir aizsargāt vērtības (LES 2. panta pirmais teikums), ${ }^{3}$ kontekstā ar tiesiskuma vērtību un šìs vērtības apdraudējumu Polijā, kā arī notikumu attīstību Eiropas Savienības Tiesā (turpmāk - Tiesa). Turklāt, ievērojot to, ka raksta tapšanas laikā LES 7. panta mehānisms “iedarbināts” pret divām

1 Visas šajā rakstā ietvertās atziṇas ir balstītas uz autores personiskajiem uzskatiem un pārliecību un nav saistošas nevienai iestādei, kurā viṇa darbojas.

2 Vispārēja piezīme par notikumiem Polijā: Tiesu reformas ietvaros ar Likumu par Augstāko tiesu, kas stājās spēkā 2018. gada 3. aprīlì, Augstākās tiesas tiesnešiem pensionēšanās vecums tika samazināts no 70 uz 65 gadiem, kā arī noteikts, ka šāds ierobežojums piemērojams ar minētā likuma spēkā stāšanos. Vienlaikus izšķirošu ietekmi uz tiesnešu disciplinārlietu ierosināšanu un norisi ieguva Polijas tieslietu ministrs. Papildu informāciju skatīt, piemēram: Soņeca V. Polija un tiesiskums. Jurista Vārds, 30.10.2018., Nr. 44 (1050), 10.-11. lpp.; Poland - Opinion on the Act on the Public Prosecutor's office, as amended, adopted by the Venice Commission at its 113th Plenary Session (Venice, 8-9 December 2017). CDL-AD(2017)028-e. Pieejams: https:/www.venice.coe.int/webforms/documents/?pdf=CDL$\mathrm{AD}(2017) 028$-e [aplūkots 24.03.2019.].

3 Levits E. Eiropas Savienība kā vērtību savienība. Jurista Vārds, 08.05.2018., Nr. 19 (1025), 39.-49. 1pp. 
dalībvalstīm, tas ir, Poliju ${ }^{4}$ un Ungāriju, ${ }^{5}$ bet raksta centrālais jautājums saistīts ar Poliju, Ungārijas situācija netiks detalizēti aplūkota. Tāpat rakstā nav apskatīta minētās dalībvalsts politiskā situācija un tās attīstība.

Vispārīgi attiecībā uz LES 7. pantu norādāms, ka tā piemērošanas pamatā jābūt dalībvalsts rīcībai, kas pārkāpj LES 2. panta pirmajā teikumā nostiprinātās vērtības un tādējādi apdraud ne tikai dalībvalstu savstarpējo uzticēšanos, bet arī no LES 4. panta 3. punkta izrietošo lojālas sadarbības principu neatkarīgi no jomas, kurā pārkāpums veikts. ${ }^{6}$ Turklāt LES 7. panta mehānisms paredz ES pilnvaras iejaukties visās jomās, ieskaitot arī tās, kuras atrodas dalībvalstu ekskluzīvā kompetencē, aizsargājot LES 2. panta pirmajā teikumā noteiktās vērtības. ${ }^{7}$

Vienlaikus LES 2. un 7. panta kontekstā jānorāda uz LES 49. pantu, kurā noteikts, ka valstij, lai tā kḷūtu par dalībvalsti, jāievēro LES 2. panta pirmajā teikumā minētās vērtības, kā arī jāapṇemas tās sekmēt. Tādējādi LES 49. pants kopsakarā ar LES 7. pantu apstiprina LES 2. panta pirmajā teikumā ietverto vērtību būtiskumu. Turklāt valstīm, iestājoties ES, jābūt ar bona fide demokrātijām, ņemot vērā, ka ES pamatlīgumi neparedz procedūru, ar kuru dalībvalsts var tikt izslēgta no ES, pamatojoties uz vērtību pārkāpumu. ${ }^{8}$ No pamatlīgumiem izriet tikai LES 7. panta mehānisms, kā arī LESD 258. pantā paredzētā iespēja Komisijai ierosināt pārkāpuma procedūru, kas arī turpmākajās nodaḷās tiks apskatīts.

\section{Tiesiskums}

Tiesiskums kā vērtība nostiprināta ne tikai LES 2. panta pirmajā teikumā, bet izriet arī no Savienības Pamattiesību hartas (turpmāk - Harta), kurai saskaṇā ar LES 6. panta 1. punktu ir tāds pats juridiskais spēks kā ES pamatlīgumiem. Hartā uzsvērts, ka ES pamatā ir demokrātija un tiesiskums, līdz ar to tiesiskuma ievērošana ir cieši saistīta ar demokrātijas un pamattiesību nodrošināšanu. Turklāt tiesiskums ir priekšnosacījums visu to tiesību un pienākumu īstenošanai, kā arī izpildei, kas izriet no ES pamatlīgumiem. ${ }^{9}$ Uz minēto norādījis arī profesors Džozefs Veilers (Joseph Weiler), nosaucot Eiropas trīs kopīgās vērtības. ${ }^{10}$

${ }^{4}$ Rule of Law: European Commission acts to defend judicial independence in Poland. Pieejams: http:// europa.eu/rapid/press-release_IP-17-5367_en.htm [aplūkots 24.03.2019.].

5 Tiesiskums Ungārijā: Parlaments aicina ES rīkoties. Pieejams: http://www.europarl.europa.eu/news/lv/ press-room/20180906IPR12104/tiesiskums-ungarija-parlaments-aicina-es-rikoties [aplūkots 24.03.2019.].

${ }^{6}$ Communication from the Commission to the Council and the European Parliament on Article 7 of the Treaty on European Union - Respect for and promotion of the values on which the Union is based. $\operatorname{COM}(2003) 0606$ final. Pieejams: https://eur-lex.europa.eu/legal-content/LV/ TXT/?uri=celex:52003DC0606 [aplūkots 24.03.2019.].

7 Komisijas paziņojums Eiropas Parlamentam un Padomei “Jauns ES mehānisms tiesiskuma nostiprināšanai”. Pieejams: https://eur-lex.europa.eu/legal-content/LV/TXT/?qid=1551121255175\&uri=CELEX:5 2014DC0158 [aplūkots 24.03.2019.].

8 Constitutionalism and the rule of law: bridging idealism and realism/edited by Maurice Adams, Tilburg University; Anne Meuwese, Tilburg University; Ernst Hirsch Ballin, Tilburg University, University of Amsterdam. Cambridge, United Kingdom; New York, NY: Cambridge University Press, 2017, pp. 446-448.

9 Komisijas paziņojums Eiropas Parlamentam un Padomei "Jauns ES mehānisms tiesiskuma nostiprināšanai”. COM(2014)0158 final. Pieejams: https://eur-lex.europa.eu/legal-content/LV/TXT/?qid=1551121 255175\&uri=CELEX:52014DC0158 [aplūkots 24.03.2019.].

10 Atjaunot uzticību Eiropas integrācijai un liberālajai demokrātijai. Jurista Vārds, 16.04.2019., Nr. 15 (1073), 16.-21. lpp. 
Šì raksta kontekstā uzmanība vēršama uz vienu no tiesiskuma elementiem, tas ir, tiesu neatkarību, kas ir obligāts priekšnoteikums tiesību uz taisnīgu tiesu īstenošanai, jo prasība pēc tiesas neatkarības ietilpst tiesību uz taisnīgu tiesu saturā un ir cieši saistīta ar varas dalīšanas principu. ${ }^{11}$ Vienlaikus jāuzsver, ka tiesas neatkarība ir arī būtisks elements savstarpējas uzticēšanās stiprināšanai starp dažādu dalībvalstu tiesu iestādēm, lai nodrošinātu sekmīgu pārrobežu sadarbības veicināšanu kopējā tiesiskuma telpā, pamatojoties uz Lìguma par Eiropas Savienības darbību (turpmāk - LESD) 81. pantā (civillietas) un 82. pantā (krimināllietas) paredzēto savstarpējas atzī̌anas principu. ${ }^{12}$

Nesens piemērs savstarpējas uzticēšanās kontekstā ir Minister for Justice and Equality ${ }^{13}$ lieta, kur centrālais jautājums bija saistīts ar to, vai izpildes tiesu iestāde, pamatojoties uz Pamatlēmuma ${ }^{14}$ 1. panta 3. punktu, var atturēties izpildìt Eiropas apcietināšanas orderi (turpmāk - EAO). Pamatlietā Polijas tiesas izsniedza trīs EAO attiecībā uz konkrētu personu. Šì persona, kas tika aizturēta İrijā, informēja İrijas tiesu, ka nepiekrìt savai nodošanai Polijai, apgalvojot, cita starpā, ka tādējādi tai tiks liegtas tiesības uz lietas taisnīgu izskatīšanu. Minētais apgalvojums tika pamatots ar Polijā realizēto tiesu reformu, kuras laikā radies apdraudējums tiesiskumam un attiecīgi neatkarīgai tiesu varai.

Tiesa, sniedzot atbildi uz İrijas tiesas uzdoto prejudiciālo jautājumu, secināja: ja izpildes tiesas rīcībā ir tādi elementi, kuri, pirmkārt, ietverti Komisijas priekšlikumā, piemērojot LES 7. pantu, un, otrkārt, vedina domāt, ka pastāv risks, ka tiks pārkāptas Hartas 47. panta otrajā daḷa garantētās pamattiesības uz lietas taisnīgu izskatī̌̌anu, šai tiesai jāpārbauda, vai pastāv iemesli uzskatīt, ka pret attiecīgo personu realizēsies minētais risks, ja tā tiks nodota konkrētajai valstij. ${ }^{15}$

Tādējādi Tiesa atzina: tāda riska, ka tiks pārkāptas personas pamattiesības uz neatkarīgu tiesu un līdz ar to šìs personas pamattiesības uz lietas taisnīgu izskatīšanu, kā tas paredzēts Hartas 47. panta otrajā daḷā, esamība piel̦auj, ka izpildes tiesu iestāde izṇēmuma kārtā atturas izpildīt EAO. Minētais Tiesas secinājums vēlreiz apliecina, ka dalībvalstī jābūt nodrošinātai neatkarīgai tiesu varai, kā arī no LES 7. panta izrietošā procedūra var būt viens no apstākḷiem, lai atkāptos no EAO izpildes.

\section{LES 7. panta mehānisms}

LES 7. pants ir politiska procedūra, kuras izmantošanai nepieciešams kvalificēts balsu vairākums. ${ }^{16}$ Vienlaikus norādāms, ka ar LES 7. panta mehānismu

11 Satversmes tiesas 18.01.2010. spriedums lietā Nr. 2009-11-01, 5. un 7. punkts.

${ }^{12}$ Eiropas Parlamenta 24.06.2013. ziņojums par pamattiesību stāvokli Ungārijā - standarti un prakse (saskaṇā ar Eiropas Parlamenta 16.02.2012. rezolūciju, 2012/2130 (INI). Pieejams: https://www.europarl. europa.eu/sides/getDoc.do?pubRef=-//EP//NONSGML+REPORT+A7-2013-0229+0+DOC+PDF+V0// LV [aplūkots 24.03.2019.].

13 Tiesas 25.07.2018. spriedums lietā C-216/18 PPU Minister for Justice and Equality.

14 Padomes 13.06.2002. pamatlēmums par Eiropas apcietināšanas orderi un par nodošanas procedūrām starp dalïbvalstīm.

15 Tiesas 25.07.2018. spriedums lietā C-216/18 PPU Minister for Justice and Equality, 50.-54., 79. punkts.

16 Jakab A., Kochenov D. The Enforcement of EU Law and Values: Ensuring Member States' Compliance. OUP, 2017. 
netiek izbeigta dalībvalsts dalība ES. ${ }^{17}$ To apliecina LES 7. panta trešā daḷa, kurā, cita starpā, noteikts, ka attiecīgai dalībvalstij var uz laiku atņemt dažas tiesības, kas izriet no pamatlīgumu piemērošanas. Piemērs šādām tiesībām ir balsstiesības Padomē. Vienlaikus norādāms, ka bez balsstiesībām Padomē LES 7. pants nesniedz to tiesību uzskaitījumu, kuras uz laiku dalībvalstij var tikt atņemtas, tādējādi l̦aujot LES 7. panta piemērotājam piepildīt šo tiesību normu ar saturu. Tomēr, skatoties tiesiskuma kontekstā, iespējams, ka LES 7. pantā iekḷauts tāds tiesību ierobežojums kā balsstiesības Padomē, jo Padomes statūtu 3. paragrāfā norādīts, ka tiesiskums līdztekus demokrātijai un cilvēktiesībām ir viens no trim Padomes balstiem. ${ }^{18}$

Vienlaikus jāpiemin, ka pastāv arī LESD 258. panta mehānisms - pamatojoties uz to, pret dalībvalsti var tikt uzsākta pārkāpuma procedūra. Tomēr šāda procedūra var tikt uzsākta tikai tad, ja noticis ES tiesību pārkāpums, piemēram, dalībvalsts nav ziņojusi par transponēšanas pasākumiem, nepareizi transponējusi direktīvu vai arī ir pārkāptas ES ekskluzīvās tiesības, ko paredz LESD 2. panta 1. punkts, skatot to kopsakarā ar LESD 3. pantu. Savukārt LES 7. pants piemērojams tikai un vienīgi, kad pastāv draudi vērtībām, kuras nostiprinātas LES 2. panta pirmajā teikumā, un šiem draudiem ir sistemātiskas iezīmes. Līdz ar to LES 7. pants ir izņēmuma mehānisms, kurš pielietojams, kad tiek apdraudētas no LES 2. panta pirmā teikuma izrietošās vērtības, nevis ikreiz, kad Komisija uzskata, ka būtu jāuzsāk pārkāpuma procedūra pret dalībvalsti. Papildus atzīmējams, ka LES 7. pants un LESD 258. pants nav viens otru izslēdzoši mehānismi. ${ }^{19}$

\subsection{Polija}

Padome pēc Komisijas priekšlikuma uzsāka pret Poliju LES 7. panta procedūru, kuras ietvaros notikusi Polijas uzklausī̌sana, un pagaidām noris LES 7. panta procedūras pirmais posms. Vienlaikus Komisija 2018. gada 2. oktobrī iesniedza Tiesā prasību pret Poliju par tiesu neatkarības principa pārkāpumu (C-619/18 Komisijal Polija). Norādāms, ka šajā lietā iestājās Ungārija, atbalstot Poliju.

Komisija savā prasībā norāda, ka Polija, samazinot Augstākās tiesas tiesnešu pensionēšanās vecumu un piemērojot to Augstākās tiesas tiesnešiem, kas pašlaik pilda savus amata pienākumus, kā arī pieškirot Polijas prezidentam rīcības brīvību pagarināt minētās tiesas tiesnešu pilnvaru termiņu, nepilda savus pienākumus, kas paredzēti LES 19. panta 1. punkta otrajā daḷā, lasot šo tiesību normu kopsakarā ar Hartas 47. pantu. Minētajā lietā Tiesa 2018. gada 19. oktobrī pieṇēma rīkojumu, kurā cita starpā

1) uzsvērts, ka prasība par tiesas neatkarību ietilpst to pamattiesību uz lietas taisnīgu izskatīšanu saturā, kurām ir kardināla nozīme kā garantijai visu tiesību aizsardzībai un kuras indivīdiem izriet no ES tiesībām; ${ }^{20}$

2) norādīts, ka šaubas par tādām dalībvalsts tiesību normām, par kurām pastāv strīds, var ietekmēt tiesu sadarbības sistēmas darbību, kas ietver lūguma sniegt prejudiciālu nolēmumu nosūtǐšanas mehānismu (LESD 267. pants).

\footnotetext{
17 Alternatives to Withdrawal from an International Organization: The Case of the European Economic Community. Israel L. Rev. 20, 1985, p. 282.

18 Likums "Par Eiropas Padomes statūtiem": LV likums. Latvijas Vēstnesis, 14.02.1995., Nr. 23 (306).

19 G̦enerāladvokāta Evgeni Tanchev 11.04.2019. secinājumi lietā C-619/18 Komisija/Polija, 50. punkts.

20 Tiesas 25.07.2018. spriedums lietā C-216/18 PPU Minister for Justice and Equality, 48. punkts.
} 
Savukārt Polija un Ungārija savos apsvērumos norāda, ka LES 19. panta 1. punkta otrā daļa un Hartas 47. pants šajā lietā nav piemērojami, kā arī atsaucas uz Associação Sindical dos Juízes Portugueses ${ }^{21}$ lietu, kurā, lai arī lūgums sniegt prejudiciālu nolēmumu attiecās uz LES 19. panta 1. punkta otrās daḷas un Hartas 47. panta interpretāciju, Tiesas spriedums tika balstīts uz pirmo minēto normu. ${ }^{22}$ Vienlaikus Polija norāda, ka saskaņā ar LES 19. panta 1. punkta otro dalıu nav jānosaka pārejas periods, samazinot tiesnešu pensionēšanās vecumu, lai garantētu viṇu neatkarību. ${ }^{23}$ Turklāt Polijas ieskatā Komisijas apgalvotā spiediena uz Polijas Augstākās tiesas tiesnešiem risks attiecībā uz Polijas prezidenta tiesībām lemt par minētās tiesas tiesnešu pilnvaru termiṇa pagarināšanu nevar tikt uzskatīts par LES 19. panta 1. punkta otrās daḷas pārkāpumu, jo tādējādi prezidents realizē savu konstitucionālo prerogatīvu. ${ }^{24}$

2019. gada 11. aprīlī šajā lietā tika pasludināti generāladvokāta Jevgenija Tančeva (Evgeni Tanchev) secinājumi, kuros cita starpā norādīts, ka LES 19. panta 1. punkta otrajai daḷai un Hartas 47. pantam ir atšķirīgas piemērošanas jomas, un Komisijai, atsaucoties uz LES 19. panta 1. punkta otro dalı kopsakarā ar Hartas 47. pantu, jāpierāda, ka Polijas īstenotie pasākumi patstāvīgi ietilpst šo tiesību normu piemērošanas jomās. ${ }^{25}$ Tā kā Komisija nav norādijusi uz apstākḷiem par Hartas 47. panta piemērošanu neatkarīgi no LES 19. panta 1. punkta otrās daḷas, generāladvokāts uzskatīja, ka Komisijas iebildumi, ciktāl tie ir pamatoti ar Hartas 47. pantu, jānoraida kā nepieņemami, ${ }^{26}$ ņemot vērā, ka prasībās, kas celtas, pamatojoties uz LESD 258. pantu, Komisijai jāpierāda iespējamā pienākumu neizpilde, jo tieši Komisijai jāsniedz Tiesai informācija, kas nepieciešama, lai pārbaudītu, vai ir notikusi pienākumu neizpilde. ${ }^{27}$ Vienlaikus generāladvokāts secināja, ka, samazinot Augstākās tiesas tiesnešu pensionēšanās vecumu un piemērojot to tiesnešiem, kas minētajā tiesā amatā iecelti pirms 2018. gada 3. aprīḷa, kā arī piešḳirot Polijas prezidentam rīcības brīvību pagarināt Augstākās tiesas tiesnešu pilnvaru īstenošanas termiņu, Polija nav izpildījusi LES 19. panta 1. punkta otrajā daḷā paredzētos pienākumus. ${ }^{28}$

Saistībā ar šo lietu (C-619/18 Komisija/Polija) paredzams, ka līdz brīdim, kamēr Tiesa neizskatīs Komisijas celto prasību un lietā netiks pieņemts spriedums, nenotiks aktīva rīcība arī LES 7. panta ietvaros. Turklāt Polijā ir atceltas tiesību normas par Augstākās tiesas tiesnešu pensionēšanās vecuma samazināšanu, tādējādi faktiski pakḷaujoties Tiesas rīkojumam. Tomēr jāvērš uzmanība, ka Polijas Augstākā tiesa vienlaikus vērsusies Tiesā arī ar vairākiem prejudiciāliem jautājumiem saistībā ar tiesu neatkarības apdraudējumu, piemēram, C-522/18 Zakład Ubezpieczeń Społecznych un apvienotās lietas C-558/18 un C-563/18 Miasto Łowicz u. c. (par prejudiciāliem jautājumiem plašāk aprakstīts 4. nodaḷā).

\footnotetext{
21 Tiesas 27.02.2018. spriedums lietā C-64/16 Associação Sindical dos Juízes Portugueses.

22 Ibid., 35., 41. un 42. punkts; G̦enerāladvokāta Evgeni Tanchev 11.04.2019. secinājumi lietā C-619/18 Komisija/Polija, 55. punkts.

${ }^{23}$ G̣enerāladvokāta Evgeni Tanchev 11.04.2019. secinājumi lietā C-619/18 Komisija/Polija, 38. punkts.

24 Ibid., 40. punkts.

25 Ibid., 60. punkts.

26 Ibid., 67. punkts.

27 Tiesas 13.11.2008. spriedums lietā C-227/07 Komisija/Polija, 67. punkts.

${ }^{28}$ Ģenerāladvokāta Evgeni Tanchev 11.04.2019. secinājumi lietā C-619/18 Komisija/Polija, 99. punkts.
} 


\subsection{Ungārija}

Ungārijas gadījumā Parlaments ar rezolūciju izteica Padomei aicinājumu veikt atbilstošas darbības, jo pastāv bažas par ES vērtību pārkāpumiem minētajā dalībvalstī. Padome pēc Parlamenta aicinājuma attiecīgi uzsāka LES 7. panta procedūras pirmo posmu, un pagaidām Ungārija nav uzklausīta. Ungārija savukārt, atbildot uz šādu rīcību, 2018. gada 17. oktobrī vērsās Tiesā (lieta C-650/18 Ungārija/ Parlaments), lūdzot atcelt Parlamenta 2018. gada 12. septembra rezolūciju, kurā Padome tiek aicināta saskaņā ar LES 7. panta 1. punktu konstatēt, ka ir droša varbūtība, ka Ungārija varētu nopietni pārkāpt vērtības, uz kuru pamata dibināta ES. Šajā prasībā Ungārija, cita starpā, norāda, ka:

1) Parlaments, balsojot par apstrīdēto rezolūciju, būtiski pārkāpis LESD 354. pantā un savā reglamentā noteikto. No balsošanas laikā nodotajām balsìm saskaitītas tikai Parlamenta locekḷu balsis par un pret, bet nav ņemtas vērā to locekḷu balsis, kuri atturējās. Minētais esot pretrunā LESD 354. pantā un Parlamenta Reglamenta 178. panta 3. punktā noteiktajam. Ungārija uzskata: ja būtu saskaitītas to locekḷu balsis, kuri atturējās, balsojuma rezultāts būtu citāds;

2) ar apstrīdēto rezolūciju pārkāpts ne tikai LES 4. panta 3. punktā noteiktais sadarbības pamatprincips, bet arī tiesiskās paļāivibas princips, jo minētajā rezolūcijā ietverti apgalvojumi, kuros ir atsauces uz tiesvedībām par pienākumu neizpildi, kuras jau tikušas pabeigtas vai vēl noris.

Pagaidām Tiesa minēto Ungārijas prasību nav izskatỉjusi, tomēr Tiesas pieņemtais nolēmums būs nozīmīgs LES 7. panta piemērošanas kontekstā, kā arī tā tvēruma noskaidrošanā citos līdzīgos gadỉjumos.

\section{Prejudiciālie jautājumi}

Saskañā ar LES 4. panta 3. punkta pirmajā dal̦ā minēto lojālas sadarbības principu dalībvalstīm to attiecīgajā teritorijā jānodrošina ES tiesību piemērošana un ievērošana. Atbilstoši ši paša punkta otrajai dal̦ai dalībvalstīm jāveic visi nepieciešamie vispārējie un īpašie pasākumi, lai nodrošinātu to pienākumu izpildi, kas izriet no pamatlīgumiem vai no ES iestāžu aktiem. ${ }^{29}$ Lai garantētu šis tiesību sistēmas īpašo iezīmju un autonomijas saglabāšanu, ar pamatlīgumiem izveidota tiesu sistēma, kuras mērķis ir nodrošināt ES tiesību saskanīgu un vienveidīgu interpretāciju. ${ }^{30}$ Viens no šādas tiesu sistēmas stūrakmeñiem radīts ar LESD 267. pantā paredzēto prejudiciālā nolēmuma tiesvedību, kuras mērķis ir nodrošināt ES tiesību vienveidīgu interpretāciju, tādējādi ḷaujot nodrošināt to saskanību, piln̄̄gu iedarbību, kā arī autonomiju. ${ }^{31}$ Polijas gadijjumā šo instrumentu izmantoja Polijas Augstākajā tiesā, ņemot vērā pien̨emto (un jau atcelto) Likumu par Augstāko tiesu.

1. Polijas Augstākā tiesa lietā C-522/18 Zakład Ubezpieczeń Społecznych uzdeva Tiesai piecus prejudiciālos jautājumus, lūdzot cita starpā skaidrojumu, kā jāinterpretē tiesu neatkarības princips kontekstā ar LES 2. panta pirmo teikumu, 4. panta 3. punktu, 19. panta 1. punkta otro daļu, lasot to kopsakarā ar Hartas 47. pantu.

\footnotetext{
${ }^{29}$ Soṇeca V. Tiesas savstarpēji abpusējā komunikācija. Jurista Vārds, 10.04.2018., Nr. 15 (1021), 22.-28. lpp.

${ }^{30}$ Tiesas 18.12.2014. atzinums 2/13, 173.-174. punkts.

${ }^{31}$ Tiesas 08.03.2011. atzinums 1/09, 67. un 83. punkts; Tiesas 18.12.2014. atzinums 2/13, 176. punkts.
} 
Šajā sakarā norādāms, ka, atbildot uz minēto Polijas Augstākās tiesas rīcību, Polijas tieslietu ministrs 2018. gada 23. augustā iesniedza Polijas konstitucionālajā tiesā pieteikumu, ${ }^{32}$ savukārt 2018. gada 4. oktobrī lūgumu ${ }^{33}$ noteikt, ka LESD 267. pants ir antikonstitucionāls. Šajā lūgumā Polijas tieslietu ministrs norāda, ka Polijas konstitucionālās tiesas kompetencē, pamatojoties uz Polijas Konstitūciju, ietilpst pārskatīt ES līgumus. Tāpat no lūguma izriet, ka praksē prejudiciālo jautājumu tvērums ir daudz plašāks, nekā tas izriet no LESD 267. panta, un Tiesa, pamatojoties uz LESD 267. pantu, skata jautājumus, kuri pārsniedz LESD 267. panta robežas. ${ }^{34}$ Tādējādi faktiski tiek apstrīdēta Tiesas kompetence atbildēt uz prejudiciāliem jautājumiem, norādot uz Polijas Konstitūcijas pārākumu pār ES tiesībām. Vienlaikus norādāms, ka uz šì raksta tapšanas brīdi Polijas konstitucionālā tiesa nav pasludinājusi spriedumu lietā, kas ierosināta, pamatojoties uz Polijas tieslietu ministra pieteikumu.

2. Apvienotajās lietās C-558/18 un C-563/18 Miasto Łowicz u. c. Polijas Augstākā tiesa uzdeva Tiesai prejudiciālo jautājumu par to, vai LES 19. panta 1. punkta otrā daḷa jāinterpretē tādējādi, ka no tās izrietošais dalībvalstu pienākums nodrošināt tiesību aizsardzības lïdzekḷus, kas nepieciešami, lai efektīvi aizsargātu tiesības tiesā, jomās, uz kurām attiecas ES tiesības, nepiel̦auj tādas tiesību normas, ar kurām likvidētas disciplinārlietu, kas tiek ierosinātas pret tiesnešiem, garantijas, politiski ietekmējot disciplinārlietu norisi un radot risku, ka disciplinārlietas varētu tikt izmantotas, lai īstenotu politisku kontroli pār tiesu nolēmumiem.

Šajā lietā nav piemērota paātrinātā tiesvedība, kā arī Tiesa nav pieṇēmusi nevienu rīkojumu, tomēr attiecībā uz uzdoto prejudiciālo jautājumu norādāms, ka tiesai viennozīmīgi jābūt aizsargātai no ārējas iejaukšanās vai spiediena, kas varētu apdraudēt tiesnešu neatkarību, izskatot tiem uzticētos strīdus. ${ }^{35}$ Ar tiesas neatkarību jāsaprot neatkarība no citiem varas atzariem, tas ir, institucionālā neatkarība, kuras garantēšana ir valsts pienākums, ${ }^{36}$ jo tikai tādā valstī, kurā varas dalīšanas princips garantē valsts varas atzaru līdzsvaru un savstarpēju kontroli, novēršot jebkura atzara uzkundzēšanās tendences un sekmējot varas mērenību, tādējādi nodrošinot neatkarīgu tiesu varu, - pastāv tiesnešu neatkarība. ${ }^{37}$ Minētais izriet arī no Cilvēka tiesību un pamatbrīvību aizsardzības konvencijas 6. panta. Turklāt prasība, ka tiesnešiem jābūt pasargātiem no jebkādas nepamatotas iejaukšanās tiesas spriešanā un tiesnešu pienākumu pildīšanā, ir ne vien pamatota un saprātīga, bet būtiska tiesiskuma nosargāšanai, ņemot vērā, ka tikai neatkarīga tiesu vara var nodrošināt taisnīgu tiesas procesa rezultātu, kas ir tiesiskuma pamats. ${ }^{38}$

Savukārt saistībā ar tiesnešu disciplināriem pārkāpumiem uzmanība vēršama uz to, ka no neatkarības prasības izriet: to personu, kas spriež tiesu, disciplināriem

\footnotetext{
32 Polijas tieslietu ministra Zbigniew Ziobro 23.08.2018. pieteikums lietā K7/18. Pieejams: https:// ipo.trybunal.gov.pl/ipo/dok?dok=F-1416117389/K_7_18_wns-pg_2018_08_23_ADO.pdf [aplūkots 24.03.2019.].

${ }^{33}$ Polijas tieslietu ministra Zbigniew Ziobro 04.10.2018. lūgums lietā K7/18. Pieejams: https:// ipo.trybunal.gov.pl/ipo/dok?dok=F694069373/K_7_18_pg_2018_10_04_ADO.pdf [aplūkots 24.03.2019.].

34 Soṇeca V. Polija un tiesiskums. Jurista Vārds, 30.10.2018., Nr. 44 (1050), 10.-11. lpp.

35 Tiesas 19.09.2006. spriedums lietā C-506/04 Wilson, 51. punkts.

${ }^{36}$ Latvijas Republikas Satversmes komentāri. VI nodaḷa. Tiesa. Sagatavojis autoru kolektīvs prof. R. Baloža zinātniskā vadībā. Rīga: Latvijas Vēstnesis, 2013, 51. lpp.

37 Satversmes tiesas 18.01.2010. spriedums lietā Nr. 2009-11-01, 7.3. punkts.

38 Ibid., 7.2. punkts.
} 
pasākumiem jābūt atbilstošiem neatkarības garantijām, kas nepieciešamas, lai izvairītos no jebkāda riska, ka šādi pasākumi tiks izmantoti kā tiesu nolēmumu satura ietekmēšanas sistēma. Minētais ir būtiski, jo noteikumu paredzēšana, kuros definēta gan rīcība, kas ir disciplinārsodāma, gan piemērojamie sodi, kuri paredz neatkarīgas instances iesaistīšanos saskaṇā ar procedūru, kura garantē Hartas 47. un 48. pantā paredzētās tiesības un kurā paredzēta iespēja apstrīdēt disciplināro iestāžu lēmumus, ir būtisko garantiju kopums, lai saglabātu tiesu varas neatkarību. ${ }^{39}$ Papildus piebilstams, ka līdzīgus apsvērumus par tiesnešu disciplināratbildību izteicis arī Augstākās tiesas tiesnesis Aigars Strupišs savās atsevišķajās domās disciplinārlietā Nr. DT-2/2017.

Vienlaikus norādāms, ka Komisija pret Poliju ir uzsākusi pārkāpuma procedūru par minēto jautājumu, 2019. gada aprīlī nosūtot formālo paziṇojumu, uz kuru Polijai jāatbild divu mēnešu laikā. ${ }^{40}$ Atbilstoši LESD 258. pantam pēc formālā paziņojuma Komisijai jānosūta Polijai argumentētais atzinums un tikai tad Komisija var vērsties Tiesā, ja pārkāpums abās minētajās pirmstiesas procedūras stadijās netiek novērsts.

\section{Secinājumi}

LES 7. panta mehānisms ir izṇēmums, kurš piemērojams tikai un vienīgi, kad tiek apdraudētas LES 2. panta pirmajā teikumā ietvertās vērtības. Tiesiskums, kas nostiprināts LES 2. pantā un izriet no Hartas, ir viena no vērtībām, kas aizsargājama, un tās apdraudējuma gadījumā var tikt uzsākta LES 7. panta procedūra, paredzot dalībvalstij tās tiesību ierobežojumus. Vienlaikus LES 7. pants šķiet diezgan neefektīvs mehānisms salīdzinājumā ar LESD 258. panta procedūru, kuras ietvaros Tiesa var lemt par finansiālām sankcijām. Tomēr minētie mehānismi ir vienīgie, kas izriet no pamatlīgumiem, ņemot vērā, ka tajos nav paredzēta iespēja izbeigt dalībvalsts dalību ES, pamatojoties uz LES 2. panta pirmajā teikumā minēto vērtību pārkāpumu.

39 Tiesas 25.07.2018. spriedums lietā C-216/18 PPU Minister for Justice and Equality, 67. punkts.

40 European Commission - Press release. Rule of Law: European Commission launches infringement procedure to protect judges in Poland from political control. Pieejams: http://europa.eu/rapid/pressrelease_IP-19-1957_en.htm [aplūkots 15.04.2019.]. 